http://www.jfas.info

\title{
THE STUDY ON THE ECONOMIC FERTILIZER REQUIREMENT FOR PADDY PRODUCTION ON A MALAYSIAN SOIL
}

\author{
F. A. Fatah ${ }^{1}$, N. Yaakub ${ }^{2,}$, R. M. Ridzuan ${ }^{1}$ and A. R. Ahmad ${ }^{1}$ \\ ${ }^{1}$ Faculty of Plantation and Agrotechnology, Universiti Teknologi MARA, 40450 Shah Alam, \\ Selangor, Malaysia \\ ${ }^{2}$ Faculty of Bioresources and Food Industry, Universiti Sultan Zainal Abidin, 22200 Besut, \\ Terengganu, Malaysia
}

Published online: 08 August 2017

\begin{abstract}
This initial exercise was to determine the paddy yield response functions with fertilizer application on a Malaysian soil in order to incorporate the economic consideration of the Malaysian fertilizer cost and paddy price variations. The yield response curve for each fertilizer could be described by a quadratic equation and this can be used in fertilizer rate prediction. The fluctuating fertilizer costs and paddy prices were used to estimate the economic fertilizer rate. It was found that the economic fertilizer rate for each $\mathrm{N}, \mathrm{P}, \mathrm{K}$ fertilizers without subsidy were $130.96 \mathrm{~kg} / \mathrm{ha}, 41.57 \mathrm{~kg} / \mathrm{ha}, 64.20 \mathrm{~kg} / \mathrm{ha}$ respectively for the chosen soil types. The simulation revealed that the economic fertilizer rate and maximum profit were influenced by the current fertilizer cost and price of paddy with the assumption that subsidies were not given for the fertilizers.
\end{abstract}

Keywords: optimum fertilizer requirement; economic; paddy production; maximum profit.

Author Correspondence, e-mail: nadzifah@unisza.edu.my

doi: http://dx.doi.org/10.4314/jfas.v9i2s.48 


\section{INTRODUCTION}

Rice is a staple food for more than 3 billion people in the world [7]. Rice is the basic food for Malaysians and it is one of the major sources of employment and income for the rural population. The government vision is to increase the self-sufficiency among the farmers. In 2011, the self-sufficiency level of rice is about 73\% [1]. The Agriculture National Key Economic Area (NKEA) is targeted to raise the total gross national income (GNI) contribution of RM21.44 billion by 2020 [8]. Although Malaysia's rice production and productivity increase each year, its yield per capita declines each year [1]. From a high of $174.6 \mathrm{~kg}$ of rice per capita in 1974, rice yield per capita has since fallen steadily to $86.0 \mathrm{~kg}$ of rice per capita in 2008 [14]. A better understanding of the various aspects of nutrient use can lead to improved crop yields and reduce the cost of production [6]. Fertilization application is one of the factors, which influence the yield components from growth early stage to mature paddy stage [12]. In [15] reported that as much as $50 \%$ of the increase in crop yields worldwide during $20^{\text {th }}$ century was due to use of chemical fertilizers [4]. In terms of economic scope the fertilizer is one of the input costs. If the farmers apply in high quantity of fertilizer in order to gain high yield, it will occur waste when the fertilizer price as input is high, the price of paddy as output is low and the profit gain is not too high. It does not balance equation. Due to the increasing cost of chemical fertilizers, fertilizer application should be efficient and sufficient in amounts for nutrients uptake by plants [6]. Many farmers are involved in production using a limited set of resources [11].

They have a bank balance (sometimes negative), various quantities of different fertility land together with its attributes of slope, rainfall and other production-defining climate components, a labor force with various attributes, a set of machinery and buildings, stock of inputs and a defined managerial ability. In combining and using this limited supply of resources the farmers must find a solution to three basic questions, factor and product problem, factor and factor problem, product and product problem [11]. To get more and more yield farmers inclined to the excess use of chemical fertilizers, but the decision on fertilizer use requires knowledge of the expected crop yield response to nutrient application which is a function of crop nutrient needed, supply of nutrients from indigenous sources and the short- 
and long-term fate of the fertilizer applied [5]. A simple definition of an optimal rate is that rate which produces maximum economic return [3]. However, choosing the fertilizer rate can be complicated because the farmer rationally decides as to whether to choose the minimum or maximum fertilizer rate or possibly some rate between these limits due to financial constraints and the cost of fertilizer [6]. Therefore, the studies strength on i) determination the paddy yield response functions with fertilizer application on soils in Malaysia, ii) determination the fertilizer cost and paddy price trends in Malaysia and iii) determination a simulation of a fertilizer requirement, the cost of fertilizer and the price of paddy management of fertilizer in term of requirement, cost and price of paddy with the optimum yield in order to achieve cost minimization and profit maximization. This to prevent waste and loss occur either the resources itself or the profit.

\section{METHODOLOGY}

The first objective in order to determine the fertilizer requirement of paddy, data collection have been carried out through library research and interview research with the various government agencies such as Agriculture Department, KADA and MARDI. Data on the cost of fertilizer and the price of paddy yield variations during a five-year interval also collected for this study. The data was collected from Pertubuhan Peladang and BERNAS. For data analysis, use the model of Excel and SPSS.

One of the equations of fertilizer requirement that can describe the paddy yield response on fertilizer rates is the quadratic equation:

$\mathrm{Y}=\mathrm{a}+\mathrm{bX}+\mathrm{cX} 2$

where $\mathrm{Y}$ is yield as the output, $\mathrm{X}$ is fertilizer application as the input and a (intercept), $\mathrm{b}$ (linear coefficient) and c (quadratic coefficient) are constant obtained by fitting data to the model function.

In order to get the slope of the response curve from Equation (1) is:

$\mathrm{dy} / \mathrm{dX}=\mathrm{b}+2 \mathrm{cX}$

In order to find the breakeven line which show the value there is not loss and not profit. The 
breakeven line is:

$\mathrm{Y}=\mathrm{CPR}(\mathrm{X})$

The slope of the break even line which represents the rice yield increase needed to pay for each increment of fertilizer is created. CPR is the slope of the breakeven line. For cost price ratio, take the Equation (3) into this equation:

$\mathrm{CPR}=\mathrm{Px} / \mathrm{Py}$

where $\mathrm{P}_{\mathrm{X}}$ is fertilizer cost and $\mathrm{P}_{\mathrm{Y}}$ is paddy price.

Maximum profit on fertilizer usage is obtained where the vertical distance between the breakeven line and response curve is the greatest. This can be determined mathematically by finding the point where a line parallel to the break-even line is tangent to the response curve.

The slope of tangent $=$ CPR from the Equation (4):

i.e $b+2 c X=C P R$

$\mathrm{X}=(\mathrm{CPR}-\mathrm{b}) / 2 \mathrm{c}$

In order to find the maximum profit of the paddy yield, insert the $\mathrm{X}$ value into the quadratic equation (Equation (1)) minus the breakeven line (Equation (3)). The answer times with the current paddy price.

i.e., (Y2-Y3) x paddy price

Lastly, from the data of calculation will be formulated in Excel program to build the model of profit and optimum fertilizer rate calculator.

\section{RESULTS}

\subsection{Yield Response}

Yield responses are often described with a quadratic equation. For a quadratic function, yields increase to a maximum with increasing soil test nutrient concentration, then decline in a mirror image of the increments [6]. According to the Table 1 show the quadratic equation for fertilizers and the regression equation appears to be useful for making predictions since the value of $R^{2}$ is close to 1 . 
Table 1. Quadratic equation

\begin{tabular}{ccc}
\hline Nutrient & Quadratic Equation & $\mathbf{R}^{2}$ \\
\hline Nitrogen & $\mathrm{Y}=-345.518+82.134 \mathrm{X}-0.309 \mathrm{X}^{2}$ & $0.507 * *$ \\
Phosphorus & $\mathrm{Y}=599.699+205.677 \mathrm{X}-2.467 \mathrm{X}^{2}$ & $0.460^{*}$ \\
Potassium & $\mathrm{Y}=1178.344+125.588 \mathrm{X}-0.967 \mathrm{X}^{2}$ & $0.591^{* *}$ \\
\hline
\end{tabular}

Note: $* *, *=$ significant at 1 and 5\% levels respectively

In order to find the value of the optimum fertilizer rate, the value of cost per ratio (CPR) from the slope of breakeven line is needed: To know how the value of CPR, economic fertilizer requirement and maximum profit was getting can see through the manual calculation. The manual calculation shows the example of $\mathrm{N}$ fertilizer calculation without subsidy. Table 2 shows the summary of all value of CPR, economic fertilizer requirement and maximum profit for each fertilizer and its optimum rate. The cost price ratio is mean the marginal product (MP), where the increase in output for a unit increase in input or the other mean the marginal return must be equal to marginal cost where the marginal cost is the increase in cost (change in input $\mathrm{x}$ input price; where the change in input is one unit, the marginal cost is $\mathrm{P}_{\mathrm{x}}$ ) and the marginal return is the change in output as input is increased by one unit multiplied by the price of a unit of output, the marginal return is $\mathrm{P}_{\mathrm{y}}[11]$.

Table 2. The value needed in order to get the maximum profit

\begin{tabular}{cccc}
\hline Fertilizer & $\begin{array}{c}\text { Cost Per } \\
\text { Ratio (CPR) }\end{array}$ & $\begin{array}{c}\text { Optimum Fertilizer } \\
\text { Rate (kg/ha) }\end{array}$ & $\begin{array}{c}\text { Maximum } \\
\text { Profit (RM/ha) }\end{array}$ \\
\hline Nitrogen & 1.20 & 130.96 & $4,954.09$ \\
Phosphorus & 0.58 & 41.57 & $4,862.45$ \\
Potassium & 1.43 & 64.20 & $5,163.66$ \\
\hline
\end{tabular}




\subsection{Manual Calculation}

\subsubsection{Without Subsidy}

1) Economic Optimum Fertilizer

a) Yield Function

$\mathrm{Y}=\mathrm{a}+\mathrm{bX}+\mathrm{c} \mathrm{X}^{2}$

(1)

$Y=-345.518+82.134 X-0.309 X^{2}$

Slope of tangent

$\mathrm{dy} / \mathrm{dX}=\mathrm{b}-2 \mathrm{cX}$

(2)

$=82.134-2(0.309) \mathrm{X}$

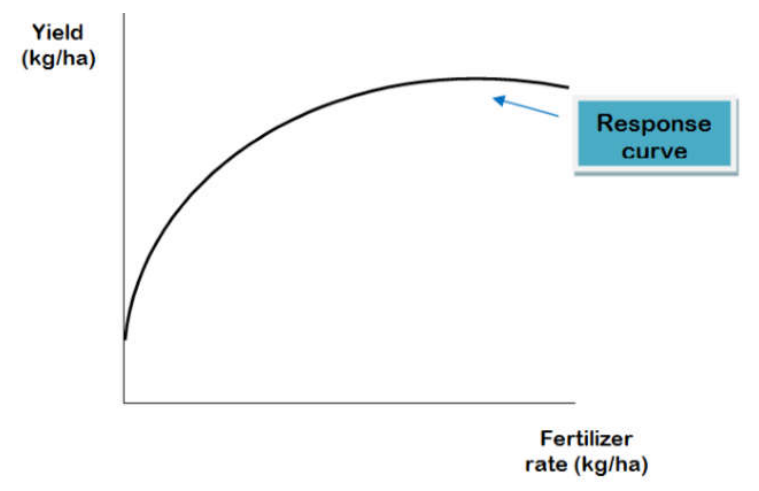

b) Breakeven Line

$\mathrm{Y}=\mathrm{CPR}(\mathrm{X})$

(3)

Slope of breakeven line

$\mathrm{CPR}=\mathrm{P}_{\mathrm{X}} / \mathrm{P}_{\mathrm{Y}}$

(4)

$\mathrm{P}_{\mathrm{X}}($ fertilizer cost $)=\mathrm{RM} 1.20 / \mathrm{kg}$

$\mathrm{P}_{\mathrm{Y}}($ paddy price $)=\mathrm{RM} 1.00 / \mathrm{kg}$

$\mathrm{CPR}=1.20 / 1.00$

$=1.20$ 


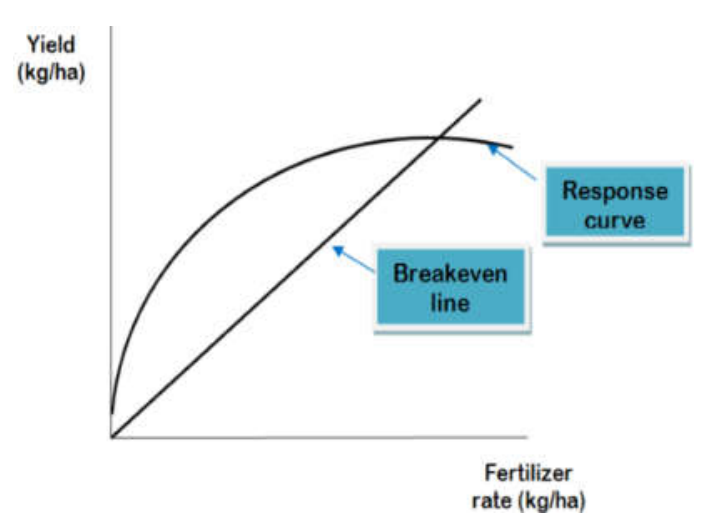

c) Slope of tangent = slope of breakeven line

$$
\mathrm{CPR}=\mathrm{b}-2 \mathrm{cX}
$$

$\mathrm{X}=(\mathrm{CPR}-\mathrm{b}) / 2 \mathrm{c}$

(6)

$X=(1.20-82.134) / 2(-0.309)$

$=130.96 \mathrm{~kg} / \mathrm{ha}$

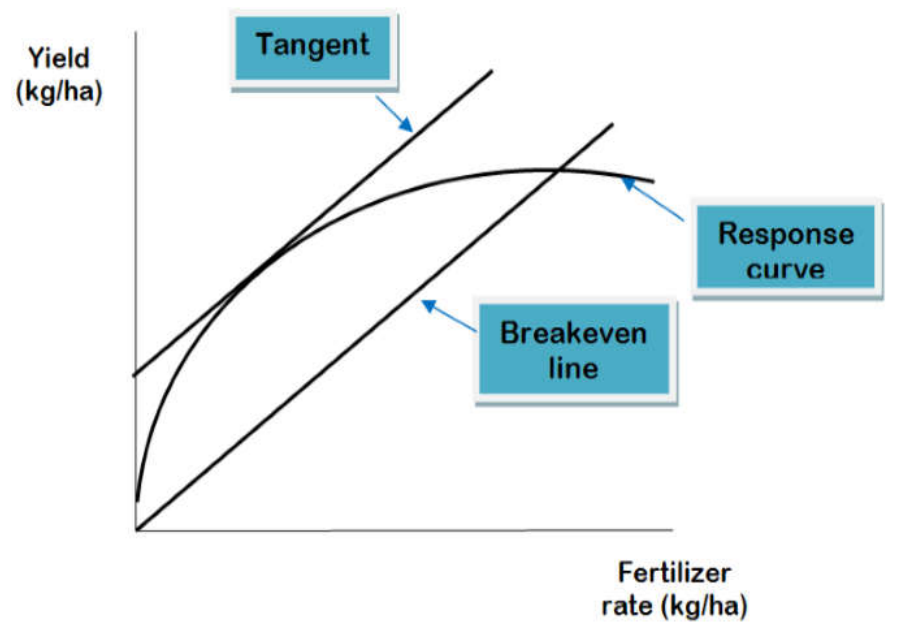

2) Maximum Profit

$$
\begin{aligned}
& \left(Y_{2}-Y_{1}\right) \\
& Y_{1}=C P R(X) \\
& =1.20(130.96) \\
& =157.15 \\
& Y_{2}=a+b X+c X^{2} \\
& =-345.518+82.134 X-0.309 X^{2} \\
& =5,111.24
\end{aligned}
$$


$\left(\mathrm{Y}_{2}-\mathrm{Y}_{1}\right) \times$ paddy price

$=4,954.09 \times \mathrm{RM} 1.00$

$=\mathrm{RM} 4,954.09$

\subsection{Current Price of Fertilizer and Paddy}

According to the staff that shifts that time, the price of fertilizer will be changed because of the fluctuating of fuel price. Table 3 shows the average change of price is according to the average price year of 2012, average five years interval and average change of price. In this study use the value average change of price in 2012.

Table 3. Types of fertilizer

\begin{tabular}{cccc}
\hline Fertilizer & $\begin{array}{c}\text { Average Price of 2012 } \\
\text { Year (RM/metric ton) }\end{array}$ & $\begin{array}{c}\text { Average Price 5 Years } \\
\text { Interval (RM/metric ton) }\end{array}$ & $\begin{array}{c}\text { Average Change } \\
\text { of Price (RM) }\end{array}$ \\
\hline Urea & 1248.00 & 1198.16 & 0.05 \\
Rock phosphate & 579.00 & 622.46 & 0.01 \\
Muriate of potash & $1,431.00$ & 1586.51 & 0.01 \\
\hline
\end{tabular}

For current paddy price, according to the manager of the factory, Mr. Mat Sehak Salleh, the market price of paddy is about RM1100 per metric ton (personal communication, September 9, 2012). The guarantee minimum price is RM750 per metric ton and the incentive that will get by the farmers is RM 248.10 per metric ton. This value of the GMP is already gives by the government and will not decrease in order to help the farmers and at the same time to increase the farmer's self-sufficiency levels. He also told that the minimum price is RM750 per metric ton, the maximum price is RM1100 per metric ton and average price is RM1000 per metric ton for Kelantan area. For government incentives will be changes from times to times and the current one is stated in Table 4 . The summary value is in the Table 4.

Table 4. Paddy price

\begin{tabular}{ccccc}
\hline Fertilizer & $\begin{array}{c}\text { Guarantee Minimum } \\
\text { Price (GMP) }\end{array}$ & $\begin{array}{c}\text { Government } \\
\text { Incentives }\end{array}$ & $\begin{array}{c}\text { Market } \\
\text { Price }\end{array}$ & $\begin{array}{c}\text { Average } \\
\text { Price }\end{array}$ \\
\hline Paddy Price & 750 & 248.10 & 1,100 & 1,000 \\
(metric ton) & & & & \\
\hline
\end{tabular}




\subsection{Economic Fertilizer Requirement and Maximum Profit}

In order to find the value of the optimum fertilizer rate, the value of cost per ratio (CPR) from the slope of breakeven line is needed. Table 2 shows the value of CPR, optimum fertilizer rate and the maximum profits for each macronutrients used in this study. All of these values for each one element are connected. In order to get the optimum fertilizer rate, need to find the CPR value first. Same with maximum profit need to use the optimum fertilizer rate inserting in both equation, quadratic and breakeven line. After minus calculation, get the maximum yield and for the purpose of getting the profit the maximum yield times with the current price of paddy.

\subsection{Model and Simulation Output}

From the result of data analysis developed a model of a fertilizer requirement, cost and price for optimum yield of paddy. By using, Excel model and SPSS model developed the model of the fertilizer requirement system in order to get the optimum yield. This is to correlate of data on fertilizer requirement cost, and the price of grain yield. This indicates the fertilizer and the economic component of the model. These basic model outputs are basically same with the theory of production function or sigmoid curve which stated by [11].

For model output of $\mathrm{N}$ fertilizer is show in some assumptions, without subsidy, partial subsidy (in term of fertilizer and price of fertilizer) and fully subsidy. This is because in this study, Urea the only one subsidized by the government. After manual and excel calculation are done (see manual calculation), Fig. 1 shows the model output of $\mathrm{N}$ fertilizer without subsidy and soil analysis. The response curve is the quadratic equation of $\mathrm{N}$ fertilizer (see Table 1). Fig. 1 shows the economic fertilizer rate is $130.96 \mathrm{~kg}$ per ha. Its maximum profit is RM4,954.09, which getting by the yield response minus the breakeven line (no loss, no gain). 


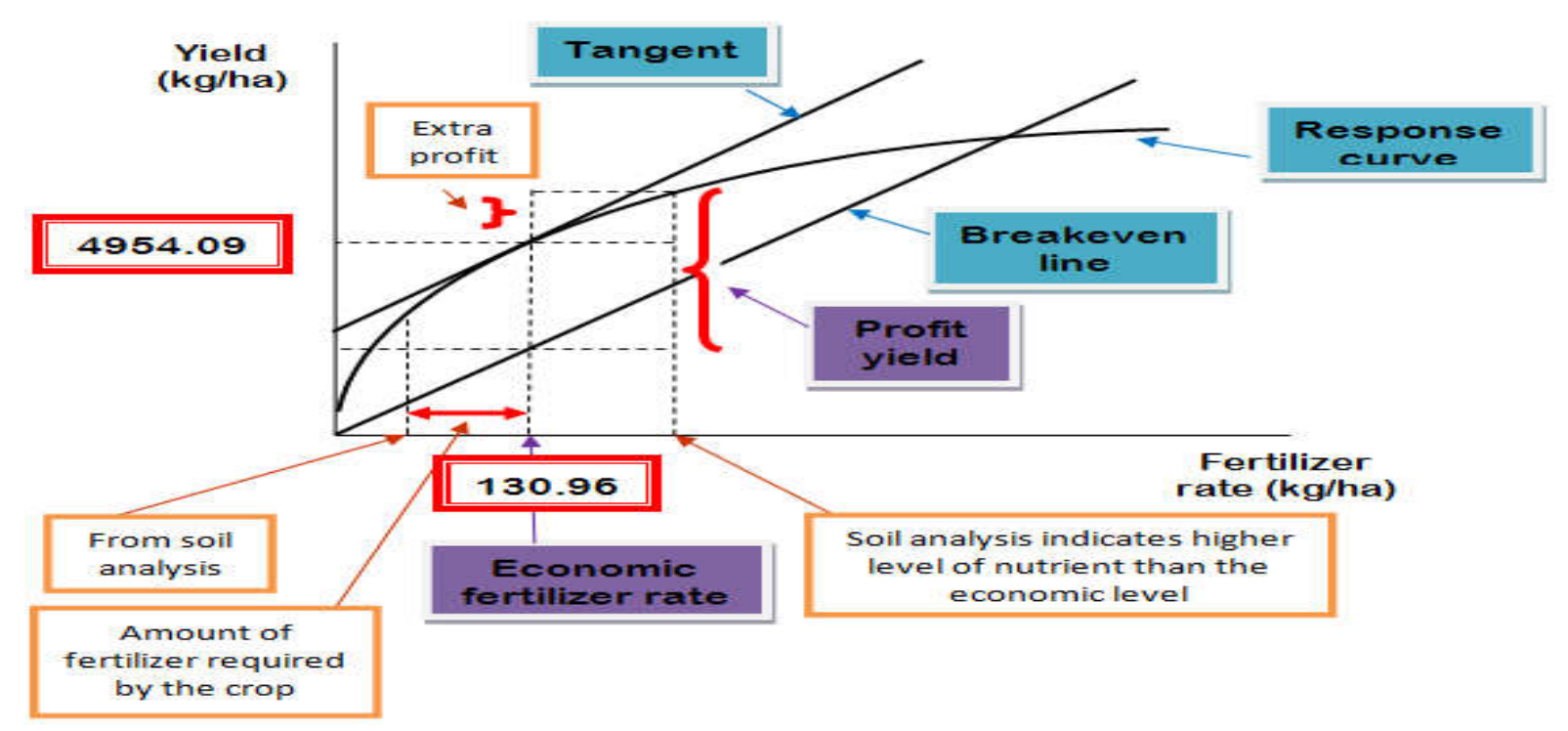

Fig.1. The model output of $\mathrm{N}$ fertilizer without subsidy

According to Fig. 1, the simulation of the $\mathrm{N}$ fertilizer, insert the value paddy price $(\mathrm{RM} / \mathrm{kg})$ at the red box and value of fertilizer price $(\mathrm{RM} / \mathrm{kg})$ at the yellow box for the first table. Then, it will get the economic optimum fertilizer rate, blue box. Same steps for the second table and it will exit the maximum profit of paddy at orange box. This excel model already formulated with the quadratic equation, CPR value, tangent equation and breakeven line equation. The farmers only need to click the current paddy price and fertilizer price into the specific box especially farmers located at the Lating soil series.

Fig. 2 and 3 show the model output of $\mathrm{N}$ fertilizer with the partial subsidy in term of fertilizer and cost of fertilizer $20 \%$, which mean the government gives the farmers fertilizer but in partial quantity and fertilizer cost respectively. For Fig. 2, we can see the breakeven line become shorter and Fig. 3 is the tangent and breakeven line become decrease. The economic fertilizer automatically changed differently from the Fig. 1. 


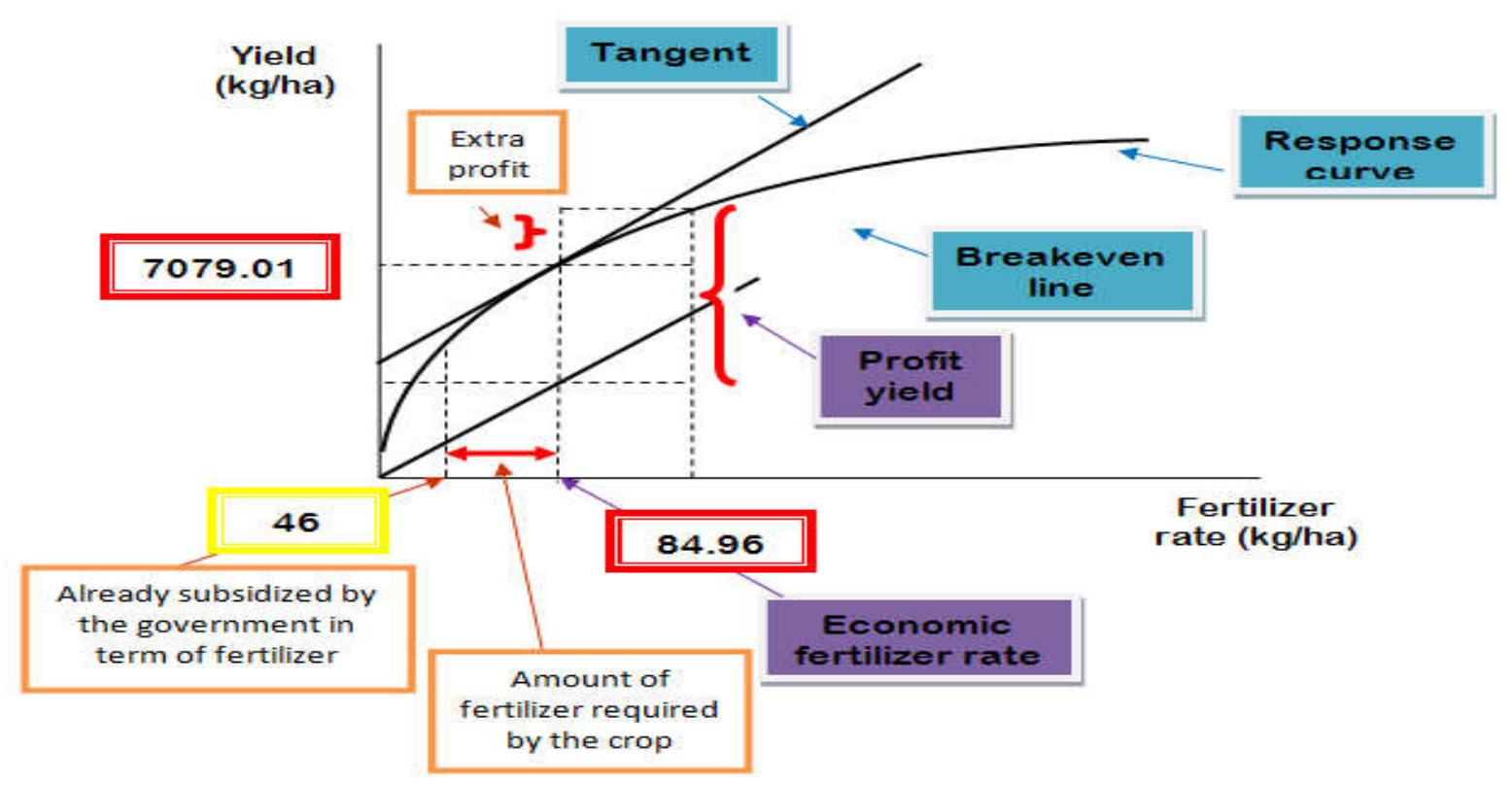

Fig.2. The model output of $\mathrm{N}$ fertilizer with partial subsidy in term of fertilizer

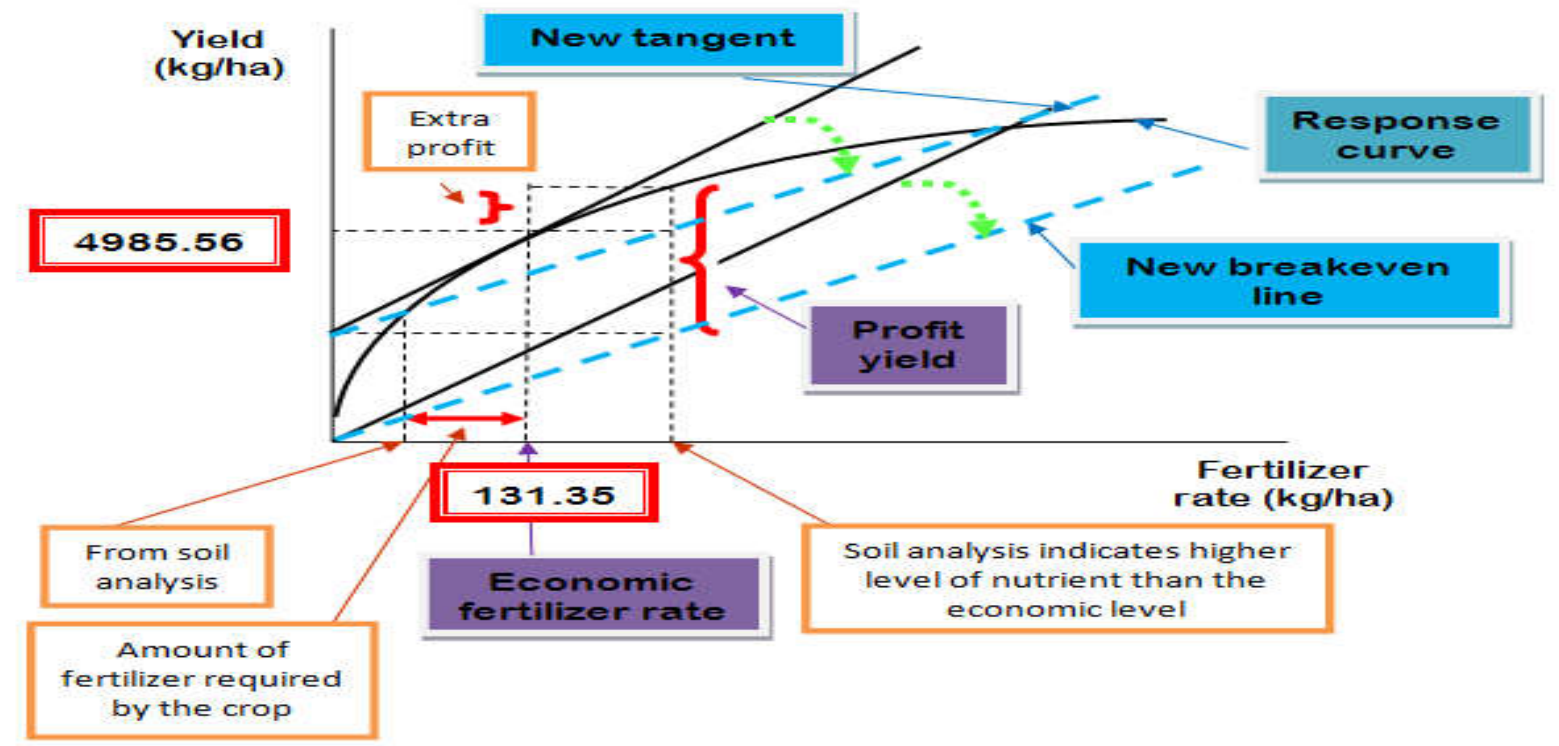

Fig.3. The model output of $\mathrm{N}$ fertilizer with partial subsidy in term of fertilizer cost $(20 \%)$

The economic fertilizer rate for both partial subsidies' item are $84.96 \mathrm{~kg} / \mathrm{ha}(130.96 \mathrm{~kg} / \mathrm{ha}-46$ $\mathrm{kg} / \mathrm{ha}$ ) and $131.35 \mathrm{~kg} / \mathrm{ha}$. For the maximum profit is RM7079.01 and RM4985.56 respectively. Fig. 2 shows the assumption price of fertilizer changed because the government gives the subsidy in term of fertilizer price. Fig. 4 is the model output of $\mathrm{N}$ fertilizer is with fully subsidy. The economic fertilizer is $132.90 \mathrm{~kg} / \mathrm{ha}$ and the maximum profit is RM 5,112.41 per ha. The economic fertilizer will become constant even the cost of fertilizer and the price of paddy are changed, but, the maximum profit will always change when the fertilizer and paddy 
price are changed.

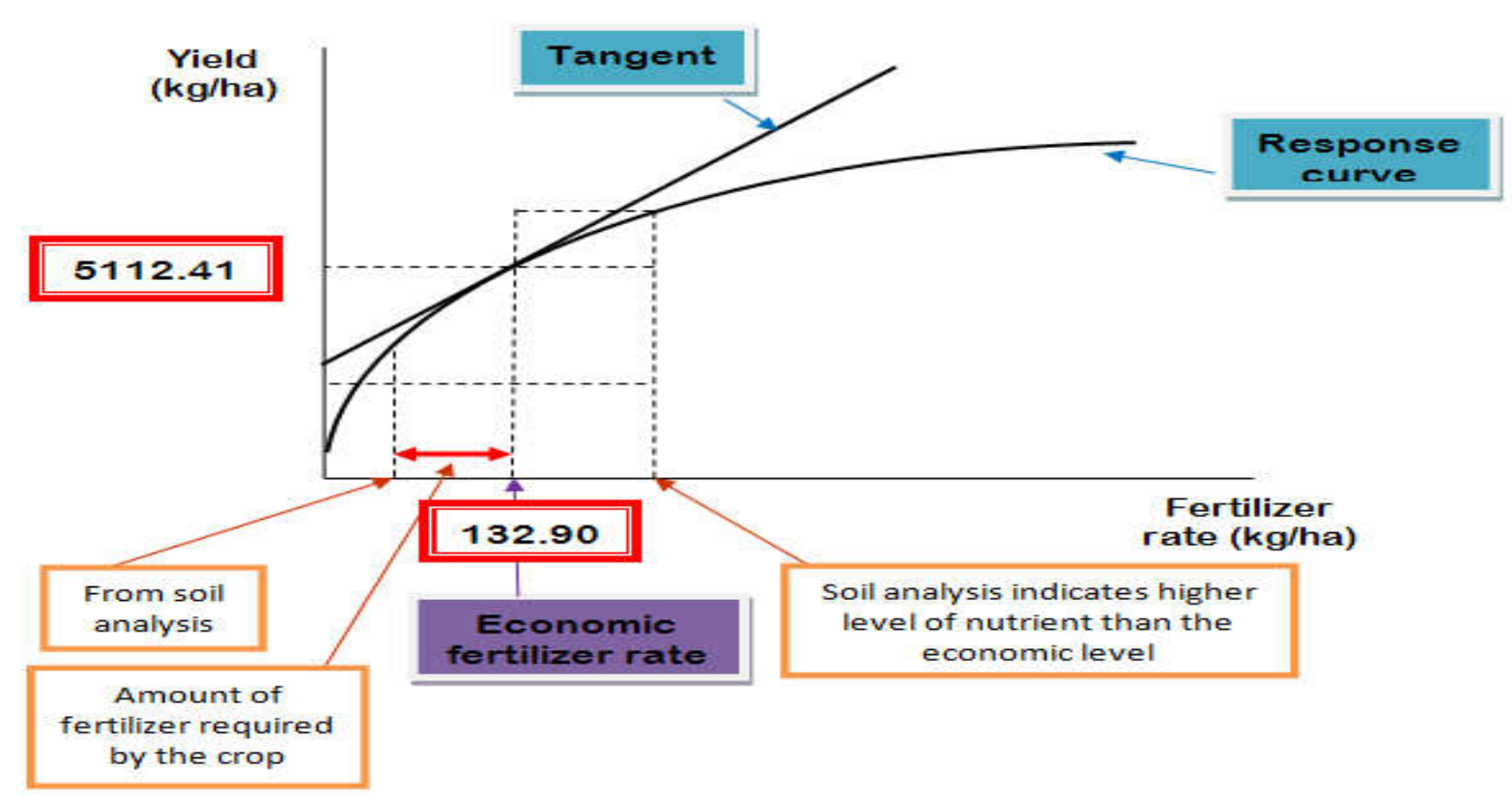

Fig.4. The model output of $\mathrm{N}$ fertilizer with fully subsidy

\section{DISCUSSION}

\subsection{Yield Response}

From the yield response, all of the quadratic equation can be used for the fertilizer rate prediction with the proven by the value of $\mathrm{R}^{2}$ and the significance at the level 1 and $5 \%$.

In this study used the quadratic equation for the yield response. This is because it is more accurate rather than linear equation. The best response model for the upland rice data obtained from the other experiments was using quadratic plateu $(\mathrm{QP})$ responding to the best fertilizer recommendation rates for Ageh, Kendinga and Strao rice varieties for maximum yield [6]. The basic equation of quadratic is:

$\mathrm{Y}=\mathrm{a}+\mathrm{bX}+\mathrm{c} \mathrm{X}^{2}$

(1)

From this basic equation (Equation (1)) after calculation by inserting the value of $\mathrm{X}$ (fertilizer rate), we will get the $\mathrm{Y}$ (value of production yield).

This equation also called yield function. The value of ' $a$ ', ' $b$ ' and 'c' is the constant value; Y and $\mathrm{X}$ is the variable value. If the ' $\mathrm{a}$ ' value is positive, it is mean that the nutrients is already 
contain in the soil and will get the yield without apply any fertilizer. If its value is negative, before start any plantation management and fertilizer application the yield already cannot produce. Another meaning of negative value is that soil indeed to apply fertilizer. For ' $b$ ' value, it's always positive because this is for linear value where here the yield always shows increasing after applying the fertilizer. ' $C$ ' value will get either positive of negative. If the value is positive, we can still apply the fertilizer because the yield will get is increasing. But if negative, its mean the production is already achieve its maximum profit and even we put fertilizer again and again, the production will reduce.

Take the result of $\mathrm{N}$ yield response as more explanation:

$\mathrm{Y}=-345.518+82.134 \mathrm{X}-0.309 \mathrm{X}^{2}$

(2)

From Equation (2), the value of ' $\mathrm{a}$ ' is negative. Therefore, the $\mathrm{N}$ level in the soil is too low and indeed to apply $\mathrm{N}$ fertilizer before planting process because if not cannot get any yield. For ' $b$ ' value, it is positive and c value is negative. The 'c' values its mean the production already achieves maximum profit and not encourages to apply above than optimum fertilizer rate.

For $\mathrm{P}$ yield function is:

$Y=599.699+205.677 X-2.467 X^{2}$

(3)

The value of ' $a$ ' for this yield function (equation 3) show positive value and its mean even without apply any P fertilizer, will get the yield. Its ' $b$ ' value also positive for linear value and 'c' value is negative which already reach maximum profit. If still apply, will get loss through the cost of fertilizer.

The yield response of $\mathrm{K}$ element is:

$\mathrm{Y}=1178.344+125.588 \mathrm{X}-0.967 \mathrm{X}^{2}$

(4)

Value of ' $a$ ' in the equation 4 is positive and this mean although do not apply the fertilizer will get the yield because the $\mathrm{K}$ level in the soil is already has. The value of ' $\mathrm{b}$ ' is positive which mean the yield is increasing by apply the fertilizer. The meaning of negative value of $\mathrm{c}$ is 
already attaining the maximum profit like $\mathrm{N}$ and $\mathrm{P}$ yield response. The value of ' $\mathrm{c}$ ' will be much smaller than ' $b$ ' so for small valued of $X$ the third term will have little impact, but as the $\mathrm{X}$ increases it will come into play thus bending the increasing line down [11].

According to the Table 3 , all the $\mathrm{R}^{2}$ value of each fertilizer is close to 1 . That mean all the quadratic equation can useful in fertilizer rate prediction even not too strong and too weak. For the proven by $\mathrm{R}^{2}$ value according to the [11], most statistical packages have these routines, so obtaining the equation is just a matter of entering the data, the proposed equation form and the package comes up with the parameters and significance statistic values (an important one is what is known as $\mathrm{R}^{2}$ and give the amount of the variation explained by the calculated equation on a scale of 0 to 1 with $\mathrm{R}^{2}=1$, indicating a perfect fit of the equation to the data and vice versa).

\subsection{Current Price of Fertilizer and Paddy}

According to the Table 3, fertilizer price shows the price of RP is lower than the others fertilizers. For Urea fertilizer, government help the farmers by give it as a subsidy. This subsidy can be in two forms either in term of the input itself or the price and of input. The RP and MOP are not government subsidy. Therefore, here farmers can reduce their cost of production. The price of fertilizer will be fluctuating because of the changing of fuel price and automatically transportation cost also changing as been told by the staff at the Pertubuhan Peladang.

For price of paddy, the market price RM1, 100 per metric ton (see Table 4). The paddy price is hold by government which called subsidy. There are three types of government interventions, these are import restriction or quota, fertilizer subsidies and price supports. With trade liberalization, the allowable policy instruments to continue supporting and subsidizing the industry will be limited. The changes in the government policy such as the removal of fertilizer subsidy for paddy production due to trade liberalization may give negative impacts to the paddy/rice industry. Even occur any environment problem which the problem we cannot control, the price will not become high. If we think as the common sense, when occur the unpredictable problem like flooding, the production will reduce because plant cannot survive in too high water level which the leaves do not get any sunrise. Here, the production 
is low while the demand is high. Therefore, the price of paddy becomes high. But, in Malaysia the government helps the residents by hold the paddy price. In [13] concluded that the overall policy implication indicated that paddy production in Malaysia cannot be sustain without fertilizer subsidy and the farmers are not willing to buy their own fertilizer. However, due to trade liberalization the allowable of continue supporting the paddy and rice industry will be limited. Thus, if the government decide to slowly or drastically remove the fertilizer subsidy, attention should be given to encourage farmers to buy their own fertilizer in order to increase the yield in order to meet the increasing demand of rice.

Both value of price, fertilizer and paddy are important for calculating the CPR and economic fertilizer rate. Either one of them or both are change, the CPR value or the economic fertilizer rate also will be change. The maximum profit also will automatically change.

\subsection{Economic Fertilizer Requirement and Maximum Profit}

For economic optimum rate, it is gain by using manual calculation value where the slope of tangent is equal with the slope of breakeven line (which means there are no loss and no profit). The slope of breakeven line or cost price ratio of $\mathrm{N}, \mathrm{P}$ and $\mathrm{K}$ fertilizer is $1.20,0.58$ and 1.43 respectively (see Table 2). These values are needed in order to get the economic fertilizer rate. The cost price ratio is mean the marginal product (MP), where the increase in output for a unit increase in input or the other mean the marginal return must be equal to marginal cost where the marginal cost is the increase in cost (change in input $\mathrm{x}$ input price where the change in input is one unit, the marginal cost is $\mathrm{P}_{\mathrm{x}}$ ) and the marginal return is the change in output as input is increased by one unit multiplied by the price of a unit of output, the marginal return is $\mathrm{P}_{\mathrm{y}}[11]$.

This optimum fertilizer requirement is $130.96 \mathrm{~kg} / \mathrm{ha}, 41.57 \mathrm{~kg} / \mathrm{ha}$ and $64.20 \mathrm{~kg} / \mathrm{ha}$ for $\mathrm{N}, \mathrm{P}$ and $\mathrm{K}$ fertilizer. This fertilizer rate is different with the fertilizer recommendation recommended by government agencies. This is because it is according to the current price of fertilizer and paddy. But, the ratio is quite similar to KADA fertilizer recommendation which $124 \mathrm{~N}: 66 \mathrm{P}_{2} \mathrm{O}_{5}: 63 \mathrm{~K}_{2} \mathrm{O}$. This is because the data mostly is gained from KADA and this optimum fertilizer rate is suitable for Lating area at Kelantan that contain the soil nutrient $32.2 \mathrm{~kg}$ of $\mathrm{N}$ which mean medium level, $102.5 \mathrm{ppm}$ (parts per million) of $\mathrm{P}$ where mean too 
high and 28.934 of $\mathrm{kg}$ of $\mathrm{K}$ which mean too low. This fertilizer rate will be changed if the price of fertilizer and paddy price are changing, use the other seed varieties and the other type of soil series. For the economic fertilizer requirement of $\mathrm{N}$ fertilizer with a few assumptions which are without subsidy, partial subsidy (in term of fertilizer and fertilizer price) and with fully subsidy, $130.96 \mathrm{~kg} / \mathrm{ha}, 84.96 \mathrm{~kg} / \mathrm{ha}, 131.35 \mathrm{~kg} / \mathrm{ha}$ and $132.90 \mathrm{~kg} / \mathrm{ha}$.

For the maximum profit, it is depend on the economic fertilizer rate and the soil analysis. The maximum profit is gain from the ' $y$ ' value of the quadratic equation (the yield response) minus the ' $y$ ' value of the breakeven line (no loss and no gain). The maximum profit of each fertilizer is RM 4,954.09, RM 4,862.45 and RM 5,163.66. Same with the maximum profit, it will be change if the price, soil analysis result, subsidy condition and optimum fertilizer rate changed. According to the soil analysis from DOA, Kota Bharu at this Lating soil area the P level is too high, $28.934 \mathrm{~kg} / \mathrm{ha}$. Therefore, the maximum profit for the P fertilizer is lower than the $\mathrm{N}$ and $\mathrm{P}$ fertilizer and the economic fertilizer rate recommended also lower than both fertilizer. For the subsidy condition as take the Urea fertilizer as assumption, there are different maximum profit between the assumptions, without subsidy, partial subsidy (in term of fertilizer and fertilizer price) and with fully subsidy, RM4,5954.09, RM7079.01, RM4985.56, RM5,112.41 respectively. The assumption of partial subsidy is the highest than the other assumptions because the cost of fertilizer is lower than the other which involved cost. If we do a comparison between both items in the partial subsidy item, the maximum profit of fertilizer subsidy is higher than the subsidy of fertilizer price. But, the maximum profit between the partial subsidy in term of the fertilizer price is higher than the without subsidy. This is strongly supported by [13], the removal of price support policy for paddy production may lead to the reduction in farmer's income and reduction in yield.

\subsection{Model and Simulation Output}

The model and simulation output are result from the manual calculation, excel and SPSS analysis. The model outputs of each fertilizer are basically from the production function or yield response curve plus with the breakeven line and the slope of quadratic equation.

The model output for $\mathrm{N}$ fertilizer is in a few assumption, without subsidy, with partial subsidy (in term of fertilizer and the fertilizer price $20 \%$ ) and with the fully subsidy. Each assumption, 
its economic fertilizer rate is about $130.96 \mathrm{~kg} / \mathrm{ha}, 84.96 \mathrm{~kg} / \mathrm{ha}, 131.35 \mathrm{~kg} / \mathrm{ha}$ and $132.90 \mathrm{~kg} / \mathrm{ha}$. We can see here for the fully subsidy is the highest that the other assumption. This is because it's the only one not involve the fertilizer cost. Therefore, this assumption cannot use this model and simulation output because the breakeven line and its slope, cost price ratio (CPR) are not involved. For partial subsidy, in term of fertilizer, the subsidy is the $46 \mathrm{~kg}$ which the urea $46 \%$ of nitrogen are given by the government to the farmers when minus with the economic fertilizer rate $130.98 \mathrm{~kg} / \mathrm{ha}$, farmer only need to add and apply $84.96 \mathrm{~kg} / \mathrm{ha}$ by themselves. The breakeven line in this model output (see Fig. 3) become constant but shorter than without subsidy model because the fertilizer rate used is reduce. For partial subsidy in term of fertilizer price with the assumption about $20 \%$ given by the government, the breakeven line in this model output become go down this is because the fertilizer price become RM0.96 and the CPR become 0.96, lower than the CPR of without subsidy (1.20). This is meant the cost become reduces. When the breakeven line move down, automatically the slope of quadratic equation (tangent) also move down. The maximum profit become higher than without subsidy, $131.35 \mathrm{~kg} /$ ha because the cost of fertilizer become lower. All assumption that can use this model and simulation output except for fully subsidy. For the economic fertilizer rate of the phosphate and potassium fertilizer is $41.57 \mathrm{~kg} / \mathrm{ha}$ and 64.20 $\mathrm{kg} / \mathrm{ha}$. Their model outputs are basically same with the $\mathrm{N}$ fertilizer model output without subsidy.

From the excel simulation (Fig. 1), we can modify in accordance to our intention. If we put the certain rate of fertilizer, we will know the yield response that result. From Fig. 1, the economic fertilizer input becomes lower if the price of fertilizer decreasing for each different paddy price. This is predicted the fertilizer and paddy price influence the optimum fertilizer rate. For maximum profit, the profit will increase when the price of paddy increase and decreasing when the fertilizer is become higher. This show that the price of paddy influences the profit and the price of fertilizer affected the cost of production.

From soil analysis the amount of nutrient is determined and the current position of the nutrient level with respect to yield can be fixed. The amount of fertilizer required can be estimated by difference between economic fertilizer rate and nutrient level from soil analysis. 
Fig. 5, 6 and 7 show the model output with the soil analysis for N, P and $\mathrm{K}$ fertilizer respectively. It shows that if the soil analysis of the $\mathrm{N}$ level in the soil is $32.2 \mathrm{~kg}$. After divided the value of $\mathrm{N}$ level in the soil $(32.2 \mathrm{~kg} / \mathrm{ha})$ with the economic fertilizer rate $(130.96 \mathrm{~kg} / \mathrm{ha})$, the result is $98.76 \mathrm{~kg} / \mathrm{ha}$. This is mean that farmers only need to buy and apply $98.76 \mathrm{~kg} / \mathrm{ha}$ optimum fertilizer rate. The estimate yield value for calculation including the soil analysis is $6612.48 \mathrm{~kg} / \mathrm{ha}$. The increment of the yield is about 1978.81 which the other word is extra profit without cost. This is because there is no cost incurred for $\mathrm{N}$ level which already has in the soil and farmers will get the yield without need to issue capital for that $\mathrm{N}$ level.

For Fig. 6 shows the model output of the P level with soil analysis. The soil analysis of P level, $102.5 \mathrm{~kg} / \mathrm{ha}$ indicates higher than the economic level, $41.57 \mathrm{~kg} / \mathrm{ha}$. The yield calculation of soil analysis is $4237.33 \mathrm{~kg} / \mathrm{ha}$. This value is below than the yield calculation for economic fertilizer rate, $4862.45 \mathrm{~kg} / \mathrm{ha}$. This is happen because it already achieved maximum profit by applying the economic fertilizer rate. Although apply higher that economic level, the yield will reduced. For this condition, the P level of soil is too higher. According to the soil science, if the nutrients is above the optimum level, growth and yield could be inhibited in some cases either because of direct toxic effects to plants or because the overabundance of one nutrient may interfere with the uptake or availability of others [2]. Here, farmers can do either no need to apply any P fertilizer if they have just a few of capital or reduced the P level in order to get maximum profits. If the $\mathrm{P}$ level in the soil is below than $102.5 \mathrm{~kg} / \mathrm{ha}$ but higher than the economic fertilizer rate, farmer no need to apply $\mathrm{P}$ fertilizer because farmers will get the extra profit which above the $4862.45 \mathrm{~kg} / \mathrm{ha}$.

The model output of K level with soil analysis is in the Fig. 7. It shows that if the soil analysis of P level is already has $28.934 \mathrm{~kg} / \mathrm{ha}$, the yield will get is $1222.98 \mathrm{~kg} / \mathrm{ha}$ without cost incurred. Farmers only need to apply $35.366 \mathrm{~kg} / \mathrm{ha}$ and will get $4354.25 \mathrm{~kg} / \mathrm{ha}$ and plus value of the yield between soil level and fertilizer application is $5579.23 \mathrm{~kg} / \mathrm{ha}$. Here, make easier to make a decision on which rate of fertilizer can be applied and the optimum profit could be obtained. This leads to efficiency of fertilizer management and help the growth of economic through this agricultural sector. 


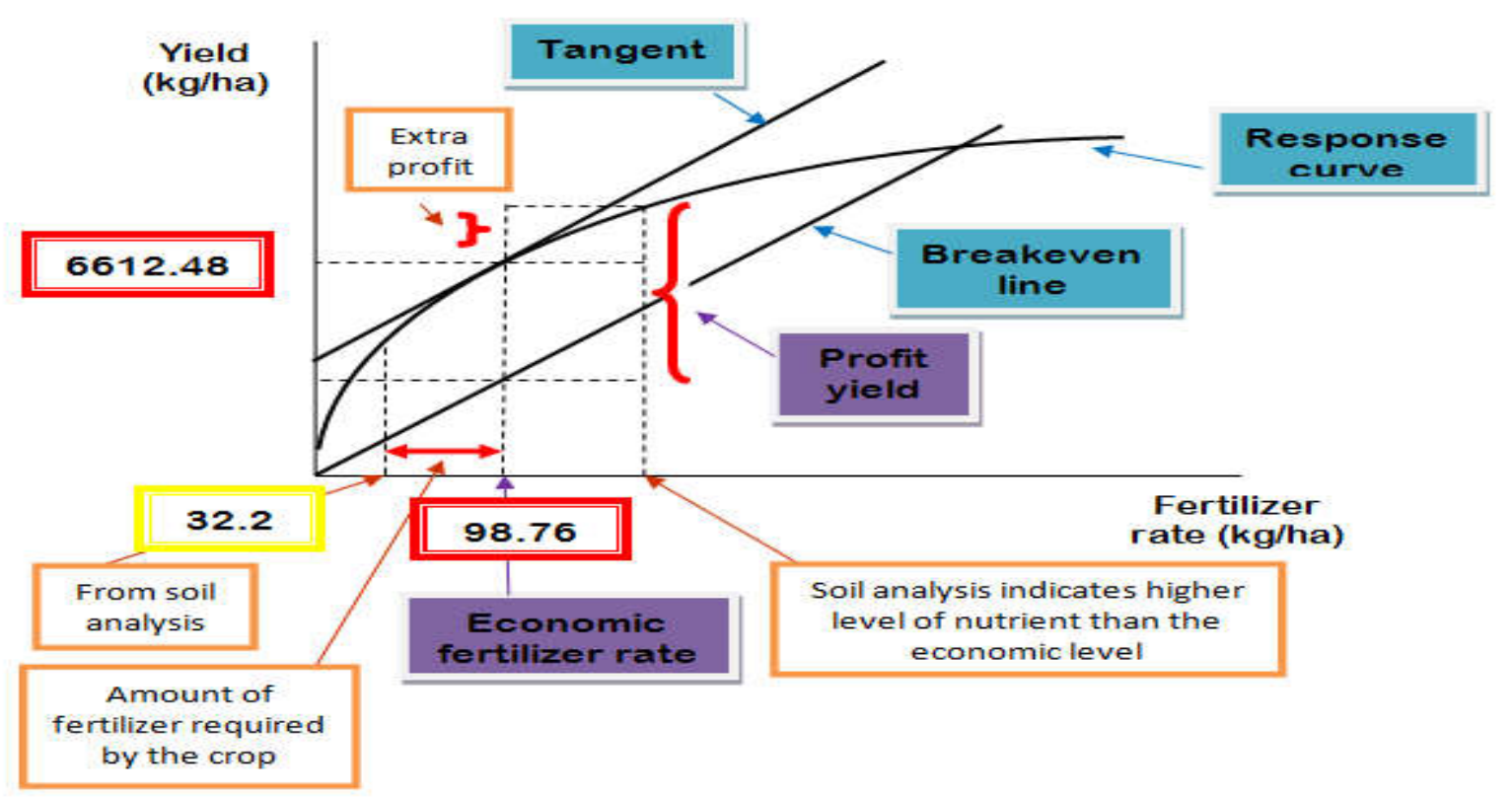

Fig.5. The model output of $\mathrm{N}$ fertilizer with soil analysis

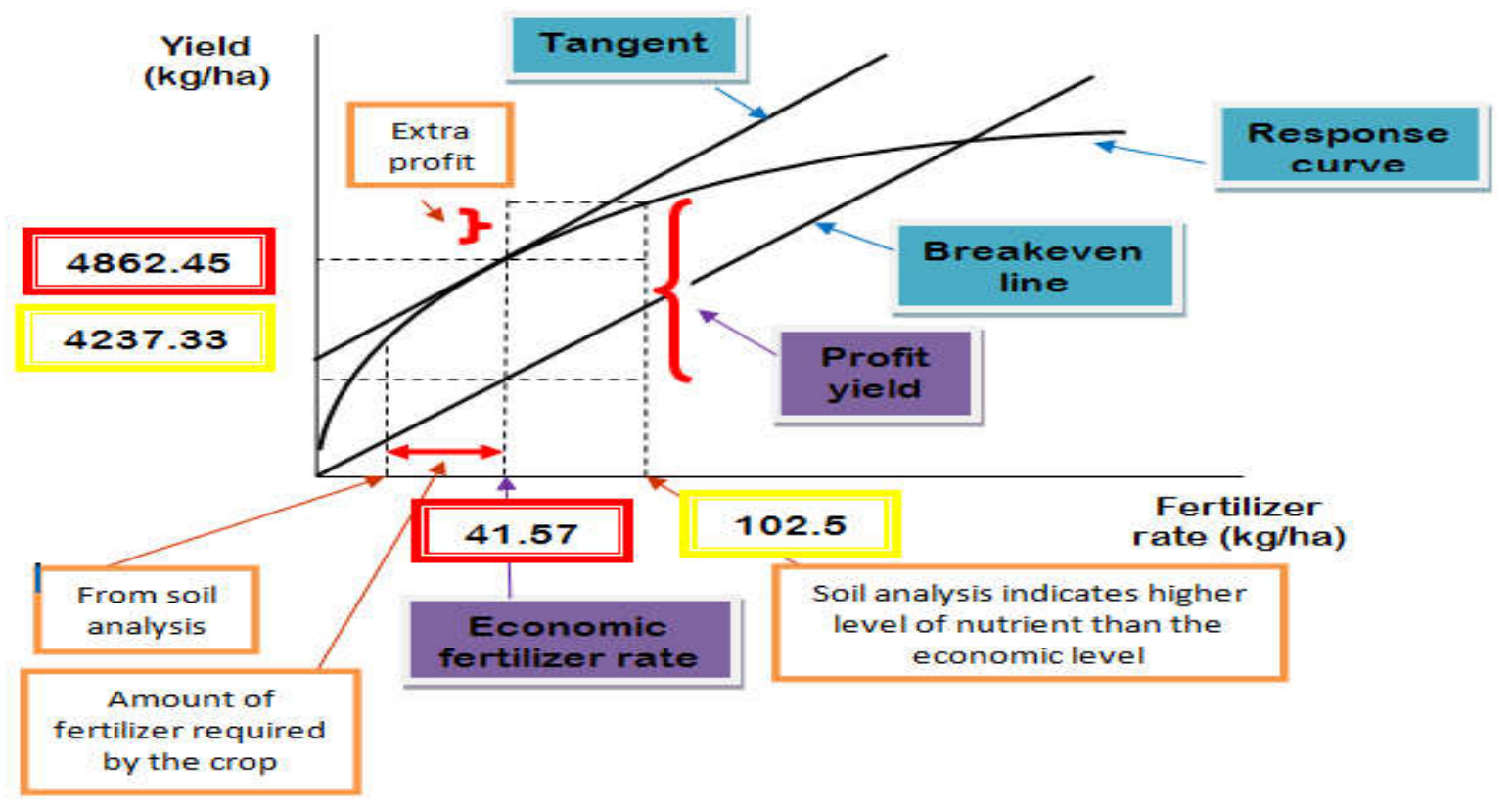

Fig.6. The model output of $\mathrm{P}$ fertilizer with soil analysis 


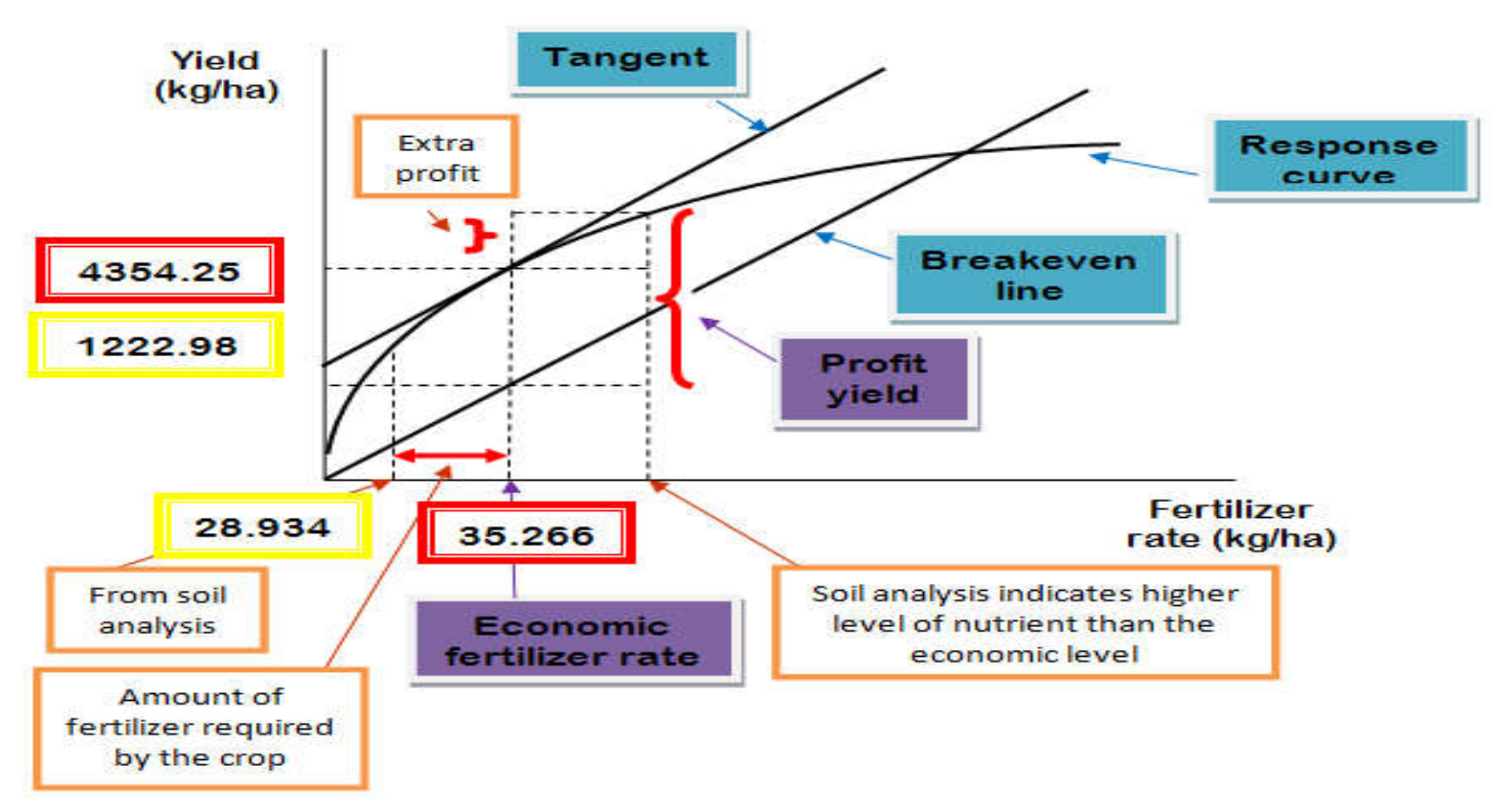

Fig.7. The model output of $\mathrm{K}$ fertilizer with soil analysis

\section{CONCLUSION}

The study can conclude that the fertilizer cost and price of paddy influence the optimum fertilizer rate application. This is automatically affected the yield and the profits. This is important for farmers especially who are the backbone of this industry. Other than that, the simulation revealed that the economic fertilizer rate and maximum profit were influenced by the current cost of fertilizer and price of paddy with the assumption that subsidies or partial subsidies were given for the fertilizers.

The recommendation is the pesticide application also gives effect to the paddy yield. It's cost of production also quite high. Therefore, its management can be analyzing like this fertilizer management in order to make sure the cost of production is in the optimum level. Other than that, the analysis also can be including with the micronutrient fertilizer. This study only focused on the macronutrient fertilizer. Plants cannot complete their life cycle in the absence of micronutrients [9]. This micronutrient also affected the yield even not too much as macronutrient. Micronutrients have been categorized as essential even though needed in minute amounts [8]. Another recommendation is combine all the managements, which involved price and cost in this analysis in order to gain the net maximum profit of paddy 
production. This study also recommended conducting the analysis about economic fertilizer requirement and yield response by using the comparison between the ratio fertilizer and the straight fertilizer. This is because functions and the response both fertilizers are different. Straight fertilizer can give the nutrient that are needed by the crop and suitable for the soil nutrients because farmers can weight it first before applied it, but the ratio fertilizer is already be appointed the rate not according to the crop requirement. It is true that before the ratio is been appointed to be as the fertilizer recommendation but, the soil nutrient and the variety of seed will always been changed.

\section{ACKNOWLEDGEMENTS}

We would like to thank to all the government agencies who involved in this study such as MARDI, Kubang Keranji, KADA, BERNAS, Pertubuhan Peladang and Department of Agriculture, Pasir Puteh for their considerable help in providing information concerning this study.

\section{REFERENCES}

[1] Akinbile C O, El-Latif K A, Abdullah R, Yusoff M S. Rice production and water use efficiency for self-sufficiency in Malaysia: A review. Trends in Applied Sciences Research, 2011, 6(10):1127-1140

[2] Bandyopadhyay P. C. Soil analysis. New Delhi: Gene-Tech Books, 2007

[3] Colwell J. D. Estimating fertilizer requirements: A qualitative approach. Oxford: Centre for Agriculture and Biosciences International, 1994

[4] Fageria N. K. The use of nutrients in crop plants. Florida: CRC Press, 2016

[5] Dobermann A, Witt C, Abdulrachman S, Gines H C, Nagarajan R, Son T T, Tan P S, Wang G H, Chien N V, Thoa V T, Phung C V. Soil fertility and indigenous nutrient supply in irrigated rice domains of Asia. Agronomy Journal, 2003, 95(4):913-923

[6] Hartinee A, Hanafi M M, Shukor J, Mahmud T M. Model comparisons for assessment of NPK requirement of upland rice for maximum yield. Malaysian Journal of Soil Science, 2010, $14: 15-25$ 
[7] International Rice Research Institute (IRRI). About us. Laguna: Rice International Research Institute, 2005

[8] Kemubu Agriculture and Development Authoritiy (KADA). Lamer-tech package for paddy plantation. Kelantan: KADA, 2012

[9] Liew Y A, Syed O S R, Husni M H A, Zainal A M A, Abdullah N A P. Effect of micronutrient fertilizers on the production of MR 219 rice (Oryza sativa L.). Malaysian Journal of Soil Science, 2010, 14:71-82

[10] Marschner H. Mineral nutrition of higher plants. London: Academic Press, 1995

[11] Nuthall P. L. Farm business management: Analysis of farming systems. Oxford: Centre for Agriculture and Biosciences International, 2011

[12] Malghani A L, Malik A U, Sattar A, Hussain F, Abbas G, Hussain J. Response of growth and yield of wheat to NPK fertilizer. Science International, 2010, 24(2):185-189

[13] Ramli N N, Shamsudin M N, Mohamed Z, Radam A. The impact of fertilizer subsidy on Malaysia paddy/rice industry using a system dynamics approach. International Journal of Social Science and Humanity, 2012, 2(3):213-219

[14] World Bank Group (WBG). Rice irrigation in Malaysia: Economic change and choice of irrigation technology. Washington DC: WBG, 2010

[15] Loneragan J F. Plant nutrition in the 20th and perspectives for the 21st century. Plant and Soil, 1997, 196(2):163-174

\section{How to cite this article:}

Fatah FA, Yaakub N, Ridzuan RM, Ahmad AR.The study on the economic fertilizer requirement for paddy production on a malaysian soil. J. Fundam. Appl. Sci., 2017, 9(2S), 777-798. 